Kumawula, Vol. 3, No.3, Desember 2020, Hal 429 - 434 DOI: https://doi.org/10.24198/kumawula.v3i3.28007

ISSN 2620-844X (online)

Tersedia online di http://jurnal.unpad.ac.id/kumawula/index

\title{
PEMBERDAYAAN MASYARAKAT DI MASA PANDEMI COVID-19 PADA IKATAN REMAJA MASJID RT.04 LOA KULU
}

\author{
Nadia Wulandari $^{1^{*}}$, Nurlita Ramadhan ${ }^{2}$, Fadillah Rahayu ${ }^{3}$, Febry Lawrenche ${ }^{4}$, Mahzbar \\ Arianto Bakhtiar ${ }^{5}$, Annisa Nurrachmawati ${ }^{6}$ \\ ${ }^{123456}$ Departemen Promosi Kesehatan, Fakultas Kesehatan Masyarakat, Universitas Mulawarman \\ *Korespondensi: nadwlndri19@gmail.com
}

\begin{abstract}
The COVID-19 Pandemic has become the number one health problem priority in Indonesia with 34.316 total cases up to the $11^{\text {th }}$ of June 2020 and will continue to increase. Therefore the government has started adopting public health approaches to prevent virus transmission such as the stay at home policy, social and physical distancing, and using mask if going out of the house for necessary things. As a result, public places such as schools, offices, and mosques are closed. Community development program is also one of the available approach because it is aimed to prevent the virus transmission through increasing the independence of the community to share information about preventing COVID-19 so the cases in their area, in this case it is in RT.04 Loa Kulu, will not increase. Community development is carried out in four stages which includes problem analysis and problem priority; planning and preparing; implementation program; and program evaluation. The program target is the mosque youth organization in RT.04 Loa Kulu because the adolescents there are very active and able to use the mosque facility which is the sound system to share information about COVID-19. Those adolescents were very enthusiastic in sharing information and implementing the preventive protocol. The information sharing utilizing the mosque sound system is an effective method because it reached a larger area and the larger community as well.
\end{abstract}

Keywords: Community Development; Mosques Youth Organization; COVID-19

\begin{abstract}
ABSTRAK
Pandemi COVID-19 menjadi prioritas masalah kesehatan nomor satu di Indonesia dengan jumlah kasus sebanyak 34.316 kasus sejak 11 Juni 2020 dan masih akan terus meningkat. Oleh karena itu pemerintah memberlakukan pendekatan-pendekatan kesehatan masyarakat untuk mencegah penularan virus tersebut seperti anjuran untuk tetap di rumah, menjaga jarak, dan menggunakan masker jika terpaksa berpergian. Akibatnya, tempat-tempat umum seperti sekolah, kantor, dan masjid pun ditutup. Program pemberdayaan masyarakat juga merupakan salah satu pendekatan yang bisa dilakukan karena bertujuan untuk mencegah penularan virus COVID-19 dengan memandirikan masyarakat untuk menyebarkan informasi terkait pencegahan COVID-19 agar tidak terjadi peningkatan kasus di daerahnya yang dalam hal ini terletak di RT.04 Loa Kulu. Pemberdayaan masyarakat dilakukan dalam empat tahapan yaitu analisis masalah dan prioritas masalah; perencanaan dan persiapan; pelaksanaan program; dan evaluasi program. Sasaran program adalah ikatan remaja masjid yang ada di RT.04 Loa Kulu karena remajanya sangat aktif dan mampu menggunakan fasilitas masjid yaitu pengeras suara masjid untuk menyebarkan informasi terkait COVID-19. Remaja-remaja tersebut antusias dan semangat dalam menyebarkan informasi dan menerapkan protokol pencegahan. Penyebaran informasi dengan pengeras suara masjid merupakan metode yang efektif karena mampu mencakup area yang luas dan masyarakat yang luas pula.
\end{abstract}

Kata Kunci: Pemberdayaan Masyarakat; Ikatan Remaja Masjid; COVID-19. 


\section{PENDAHULUAN}

Pada akhir Desember 2019 dunia digemparkan dengan adanya berita kemunculan virus baru yang merupakan coronavirus jenis baru (SARS-CoV-2), kemunculan virus ini bermula di wilayah Wuhan, Cina. Novel Corona Virus (COVID-19) yang dikenal dengan nama Virus Corona adalah jenis baru dari coronavirus yang menular dari manusia ke manusia. Virus Corona merupakan satu keluarga besar virus yang menyebabkan penyakit rungan sampai berat, seperti pilek dan penyakit yang serius. Virus ini dapat menyerang siapa saja, baik balita, anak-anak, orang dewasa, orang tua, ibu hamil, maupun ibu yang sedang menyusui. Virus ini sangat menular dengan cepat dan telah menyebar ke wilayah diluar Cina dan ke hampir seluruh negara di dunia (Yuliana, 2020).

Menurut Kementrian Kesehatan tahun 2019 mengatakan bahwa infeksi virus Corona atau COVID-19 dapat menyebabkan penderitanya mengalami gejala flu, seperti hidung berair, nyeri tenggorokan dan demam serta dapat mengalami gejala penyakit infeksi pernapasan berat, seperti demam tinggi, batuk berdahak bahkan berdarah, sesak napas dan nyeri dada. Namun, secara umum ada 3 gejala yang bisa nemandakan seseorang terinfeksi virus corona, yaitu:
a. Demam $>38^{\circ} \mathrm{C}$
b. Batuk dan pilek
c. Sesak napas yang membutuhkan perawatan di RS
d. Sakit tenggorokan
e. Letih dan lesu

Gaya hidup masyakat Indonesia sekarang ini menjadi salah satu bagian yang sangat berpengaruh dalam menyikapi masalah yang serius dengan adanya COVID-19 saat ini telah banyak kasus positif virus corona yang terdeteksi di beberapa wilayah daerah-daerah Indonesia. World Health Organization (WHO) telah meningkatkan status Corona atau COVID19 secara global menjadi pandemi. Pemerintah Indonesia telah meningkatkan kewaspadaan terutama dalam hal mencegah penyebaran kasus. Adapun himbauan kepada masyarakat untuk dapat mencegah penularan virus corona yaitu dengan melakukan social distancing, menggunakan masker saat berpergian, dan rutin mencuci tangan menggunakan sabun.

Pendemi virus corona masih terus terjadi di sebagian negara di dunia termasuk di Indonesia. Seiring bertambahnya jumlah kasus yang dikonfirmasi, jumlah pasien sembuh dan meninggal pun turut meningkat. Tetapi adapula pasien yang sembuh dengan adanya penanganan dari instansi kesehatan. kabar kesembuhan ini datang dari beberapa provinsi yang melaporkan adanya kasus corona di wilayahnya. Berdasarkan fakta yang telah diuraikan diatas, terjadi peningkatan peluang kegiatan berbasis online dalam masyarakat saat ini, sebagai mahasiswa promosi kesehatan perlu mempertimbangkan cara-cara tambahan untuk merancang instruksi kegiatan online secara efektif untuk melakukan pemberdayaan masyarakat dalam penyebaran informasi bermanfaat mengenai COVID-19. Dikarenakan sampai saat ini, belum terdapat terapi antiviral spesifik dan vaksin dalam penanganan COVID19.

Pemberdayaan adalah sebuah proses penyadaran masyarakat yang dilakukan secara transformatif, partisipatif, dan berkesinambungan melalui peningkatan kemampuan dalam menangani berbagai persoalan dasar yang dihadapi dan meningkatkan kondisi hidup sesuai dengan harapan (Aziz, 2009; Solihah, 2020).

Pemberdayaan masyarakat bisa dilakukan dengan cara melakukan pemetaan terlebih dahulu apa yang menjadi masalah serta kebutuhan mendasar dari masyarakat. Setelah itu baru dilakukan langkah-langkah untuk memecahkan masalah tersebut dengan cara memberikan pelatihan non formal terkiat potensi yang ada di wilayah tersebut (Gunawan et al., 2020; Karlina et al., 2020; Nugrahaningsih et al., 2019). Pemberdayaan masyarakat dalam penanganan COVID-19 sangat penting dan merupakan kebutuhan mendesak untuk segera dilaksanakan mengingat kegiatan ini bertujuan untuk 
meningkatkan kemampuan masyarakat khususnya di wilayah Loa Kulu dalam penyeberan informasi bermanfaat mengenai COVID-19 dan melawan berita hoaks yang beredar di lingkungan masyarakat.

\section{METODE}

Jenis penelitian yang dilakukan adalah Observasional Deskriptif. Yang digunakan untuk melihat dan mengamati fenomenafenomena (perilaku kesehatan dalam menangani COVID-19) yang ditemukan, baik itu berupa faktor risiko, maupun suatu efek atau hasil yang berkaitan dengan kasus COVID-19.

Berdasarkan metode tersebut setelah dilakukan pengamatan secara langsung mengenai keadaan masyarakat melalui diskusi online dan pengisian angket melalui google form. Populasi dalam penelitian ini adalah warga yang bertempat tinggal di wilayah RT 004 Kecamatan Loa Kulu, Kabupaten Kutai Kartanegara, Provinsi Kalimantan Timur. Teknik pengambilan data yang dilakukan dalam penelitian ini adalah dengan melakukan observasi dan diskusi .Observasi ini dimaksudkan untuk mengidentifikasi keadaan masyarakat di wilayah RT.004.

Sumber data dalam penelitian ini merupakan data primer dengan melakukan observasi lapangan di wilayah RT.004 Kecamatan Loa Kulu yang bertujuan untuk mengetahui kondisi dan gambaran umum lokasi yang digunakan selama pemberdayaan dengan maksud sebagai penentuan metode pelaksanaan kegiatan dan pengambilan data primer juga didapatkan melalui diskusi online bersama masyarakat yang bertujuan untuk memperoleh langsung informasi tentang perilaku masyarakat dalam menghadapi COVID-19. Pada penelitian ini juga digunakan data sekunder yang berisikan profil Kecamatan Loa Kulu yang berisi data mengenai sarana dan prasarana serta fasilitas umum yang berada di wilayah setempat. Penyajian dan analisis data disajikan dalam bentuk pie chart dengan tujuan agar terlihat lebih menarik dan lebih mudah dalam menganalisis data-data tersebut.

\section{HASIL DAN PEMBAHASAN}

Data yang diperoleh dari penelitian ini dikumpulkan kemudian dianalisis sebagai bahan pertimbangan dalam pembuatan suatu program promosi kesehatan atau kegiatan pemberdayaan dimasyarakat, berdasarkan hasil identifikasi dan penentuan prioritas masalah adapun kegiatan yang dilakukan adalah "Pemberdayaan Masyarakat Mengenai COVID-19 Melalui IRMA (Ikatan Remaja Masjid) di Kecamatan Loa Kulu, Desa Loa Kulu Kota" dalam rangka membangun kemampuan atau potensi masyarakat dengan mendorong dan membangkitkan kesadaran yang dimiliki serta sebagai upaya dalam memerangi penyebaran COVID-19. Kegiatan pemberdayaan masyarakat ini diharapkan dapat memberikan manfaat terhadap masyarakat sekitar, hai ini dilakukan karena letak Desa Loa Kulu Kota sebagai jantung kota daerah dari Kecamatan Loa Kulu sendiri yang berpotensi terjadinya penyebaran COVID-19 kepada masyarakat. Posisinya sebagai daerah strategis menjadi sumber ekonomi terbesar di Kecamatan Loa Kulu yang mana didalamnya terdapat pasar utama, industri tempe dan tahu serta pusat pendidikan dan pusat gedung olahraga. Sehingga diambil keputusan untuk program pengabdian masyarakat dilaksanakan pada daerah tersebut.

Program Pengabdian Masyarakat (PPM) merupakan input dari mata kuliah Pemberdayaan Masyarakat, Departemen Promosi Kesehatan Fakultas Kesehatan Masyarakat Universitas Mulawarman Samarinda. Judul PPM ini adalah "Pemberdayaan Masyarakat Mengenai COVID-19 Melalui IRMA (Ikatan Remaja Masjid) di Kecamatan Loa Kulu, Desa Loa Kulu Kota" secara online adapun lokasi Pemberdayaan Masyarakat yang dipilih yakni di Kecamatan Loa Kulu dengan target masyarakat umum di RT 04. Pemilihan lokasi ini didasari oleh adanya kemungkinan melakukan pemberdayaan masyarakat secara online khususnya remaja yang cukup aktif di wilayah tersebut yang terorganisir dan 
tergabung dalam organisasi Ikatan Remaja Masjid (IRMA). Mengapa memilih remaja hal ini dikarenakan tidak hanya keaktifan serta telah terorganisirnya mereka namun remaja adalah sasaran yang sesui untuk menyampaikan pesan atau kegiatan kepada masyarakat sekitar.

Pemberdayaan Masyarakat merupakan upaya untuk meningkatkan kesadaran, kemauan dan kemampuan bagi setiap orang untuk hidup bersih dan sehat agar penyebaran COVID-19 dapat dicegah dengan baik sehingga tercapainya peningkatan derajat kesehatan masyarakat yang setinggi-tingginya dapat terwujud. Tujuan umum pemberdayaan masyrakat ini adalah, a) perubahan perilaku lebih baik, b) meningkatnya peran remaja dalam menyebarkan informasi mengenai protokol COVID-19 yang benar, c) dapat memanfaatkan fasilitas umum masjid dalam penyebaran informasi protokol COVID-19.

Startegi pencapaian dari kegiatan pemberdayaan ini adalah 1) Melaksanakan Protokol Kesehatan Pencegahan COVID-19. Tujuanya yaitu mendorong adanya kegiatan pengecekan suhu sebelum memasuki masjid, melakukan cuci tangan dengan sabun dan air mengalir agar masyarakat terbiasa untuk melakukan pola hidup bersih dan sehat. 2) Memanfaatkan Media Untuk Menyebarkan Informasi. Yaitu dengan memanfaatkan saund system atau toa masjid sebagai sarana untuk mnyampaikan informasi mengenai COVID-19 dan dilakukanya pemasangan himbauan di sekitaran masjid

Hasil evaluasi terhadap kegiatan pemberdayaan masyarakat menunjukan bahwa remaja pengurus masjid di wilayah telah melakukan edukasi dengan menyampaikan informasi pencegahan COVID-19 dan melaksanakan sebagian protokol kesehatan seperti penyediaan tempat cuci tangan, penyedian himabaun, penyediaan pembatasan sosial dan pengecekan suhu. Semua kegiatan tersebut dilakukan dengan baik.

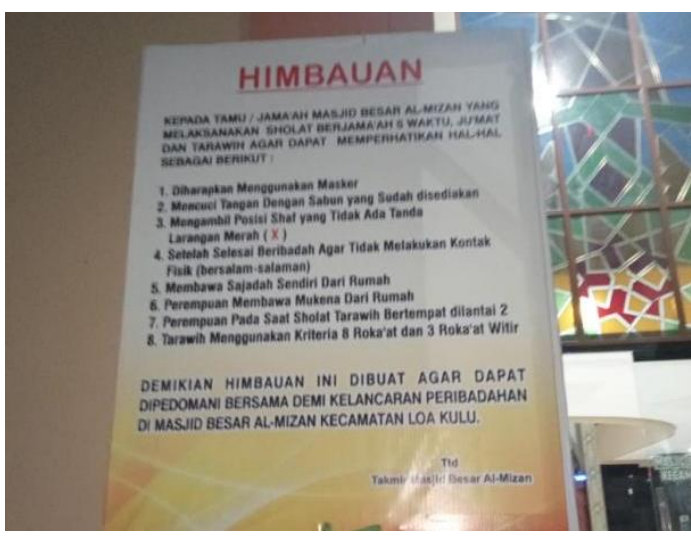

Gambar 1. Pemasangan Himbauan di Masjid Besar AL-Mizan Kecamatan Loa Kulu

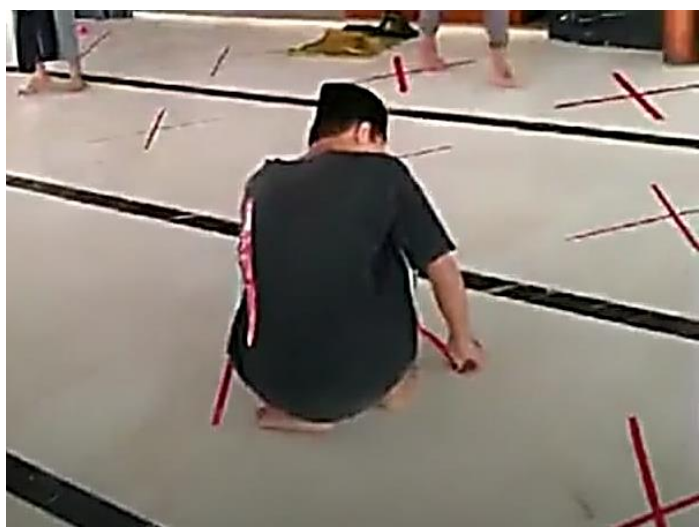

Gambar 2. Pengerjaan untuk pembatsan sosial di Masjid Besar AL-Mizan

Kecamatan Loa Kulu

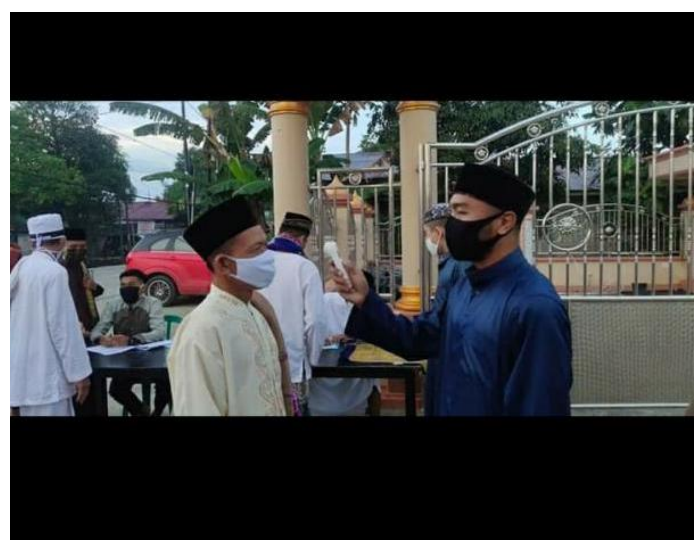

Gambar 3. Pengecekan suhu di Masjid Besar AL-Mizan Kecamatan Loa Kulu 


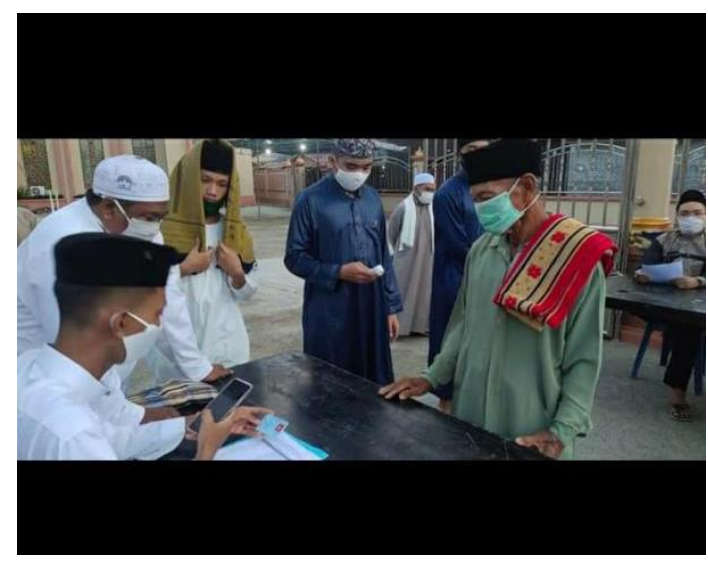

Gambar 4. Pedataan Sebelum Masuk di Masjid Besar AL-Mizan Kecamatan Loa Kulu

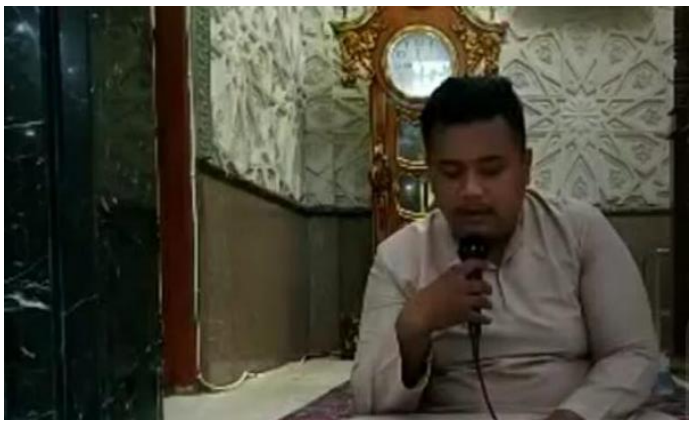

Gambar 5. Edukasi Melalui Toa Masjid di Masjid Besar AL-Mizan Kecamatan Loa Kulu

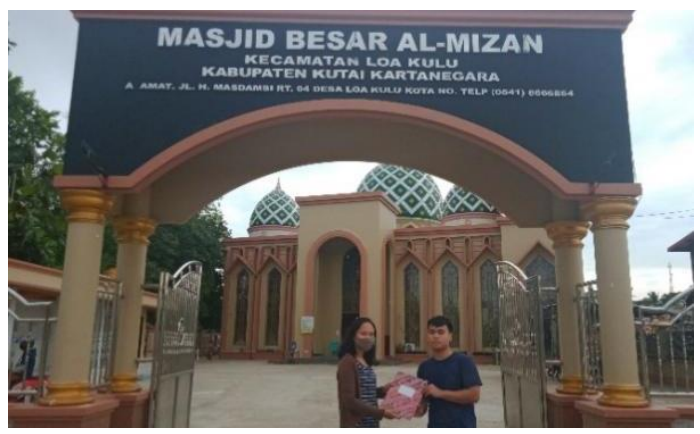

Gambar 6. Bukti Serah terima melaksankan program di Masjid Besar AL-Mizan

Kecamatan Loa Kulu

Hasil Oberservasi dari peneliti menunjukan aktivitas yang dilakukan masyarakat dalam menjalankan kegiatan sehari - hari termasuk dalam menjalankan peribadatan di Mesjid AL Mizan Kecamatan Loa Kulu kutai kartanegara. Bahwa sebagian besar masyarakatnya telah melaksanakan protocol kesehatan dan program pemberdayaan masyarakat terhitung sejak bulan suci
Ramadhan sampai dengan pelaksanaan Idul Fitri dan ditetapkanya status new normal. Sejumlah lokasi yang krusial di daerah tersebut di fungsikan dengan normal seperti pasar, pertokoan, tempat ibadah lainnya walaupun ditengah - tengah pandemi COVID-19. Sehingga Program promosi kesehatan pada pemberdayaan dimasyarakat ini telah berjalan sesuai dengan perencanaanya.

\section{SIMPULAN}

Dari hasil penelitian dapat disimpulkan bahwa peran masyarakat dan sejumlah lembaga swadaya masyarakat seperti organisasi IRMA (Ikatan Remaja Masjid) sangat berperan penting dalam memutus rantai penyebaran COVID-19 di loa kulu kota kutai katanegara. Hal Ini dibuktikan dengan adanya program program yang telah dibuat agar masyarakat dapat menerapkannya sebagai upaya pencegahan COVID-19 dalam meningkatkan derajat kesehatan masyarakat telah terlaksana dengan baik. Program pemberdayaan masyarakat dengan pemberian informasi mengenai cara pencegahan COVID-19 yang kemudian disampaikan oleh IRMA memotivai masyarakat untuk melakukannya. Sehingga masyarakat dengan sendirinya mengalami transisi perubahan perilaku secara signifikan. Oleh karena itu sebaiknya program ini dapat dilakukan dengan intens sebagai pengingat di wilayah tersebut.

\section{UCAPAN TERIMAKASIH}

Terima kasih yang setinggi-tingginya kami ucapkan kepada para dosen pembimbing dan teman-teman yang mendukung atas program Pemberdayaan Masyarakat dimasa Pandemi COVID-19 pada Ikatan Remaja Masjid RT.04 Loa Kulu.

\section{DAFTAR PUSTAKA}

Azis Muslim. 2009. Metodologi Pembangunan Masyarakat. Teras. Yogyakarta

Gunawan, W., Setiawan, S., \& Muttaqin, Z. (2020). Pelatihan Sabun Herbal kepada Kelompok Kebersihan, Keindahan dan 
Kenyamanan Lingkungan (K3L) Universitas Padjadjaran sebagai Program Pemberdayaan Masyarakat Nano Sosial Entrepreneur. Kumawula: Jurnal Pengabdian Kepada Masyarakat, 3(1), 87. https://doi.org/10.24198/kumawula.v3i1. 24696

Karlina, N., Halim, H. A., Azizi, M. F., Athusholihah, A., \& Tarliyah, A. (2020). Pemberdayaan Jiwa Kewirausahaan Masyarakat Desa Cisempur Dan Pendampingan Kewirausahaan Berbasis Ecommerce. Kumawula: Jurnal Pengabdian Kepada Masyarakat, 2(3), 262.

https://doi.org/10.24198/kumawula.v2i3. 24592

Kemenkes RI. 2019. Pedoman Kesiapsiagaan Menghadapi Infeksi Coronavirus (2019nC0V). Kementrian Kesehatan RI (P2P). Jakarta

Nugrahaningsih, P., Sari, V. K., \& Hapsari, A. A. (2019). Pemberdayaan Industri Pengelolaan Bank Sampah Beraksi Berbasis Greenpreneurship Di Bank Sampah Beraksi Desa Pojok. Kumawula: Jurnal Pengabdian Kepada Masyarakat, 2(2),

145. https://doi.org/10.24198/kumawula.v2i2. 23618

Solihah, R. (2020). PEMBERDAYAAN MASYARAKAT MELALUI PEMANFAATAN PEKARANGAN SEBAGAI WARUNG HIDUP KELUARGA DI DESA KUTAMANDIRI KECAMATAN TANJUNGSARI. Kumawula: Jurnal Pengabdian Kepada Masyarakat, 3(2), 204-215.

https://doi.org/https://doi.org/10.24198/k umawula.v3i2.26436

Yuliana. 2020. Coronavirus Disease (COVID19). Fakultas Kedokteran. Universitas Lampung. Bandar Lampung. 